\title{
Religious Subjectivity Mahasiswa Pendidikan Keguruan
}

\author{
Jumal Ahmad \\ Sekolah Pascasarjana UIN Jakarta, 1. Kertamukti No. 5, Pisangan Barat, Ciputat Timur, \\ Cireundeu, Kec. Ciputat Tim., Kota Tangerang Selatan \\ ahmadbinhanbal@gmail.com
}

\begin{abstract}
Existing research demonstrates a positive relation between religion and identity among adolescents. The subject of this study was students of Faculty of Education and Teacher Training, Syarif Hidayatullah State Islamic University Jakarta, who were taken by simple random sampling technique. The data were collected through semi-structural interviews using the Abdullah Sahin's subjectivity mode based on James Marcia's framework. Thus, this study finds that the subject are in foreclosure, moratorium and achievement status, and no respondents are in diffusion status. The novelty of this research is that religion provides a distinct settinh for identity exploration and commimtment trough offering ideological, social and spiritual context.
\end{abstract}

Keywords: religious subjectivity, late adolescence, semi structural interview

\begin{abstract}
Abstrak
Penelitian ini menunjukkan adanya hubungan positif antara agama dan identitas di kalangan remaja. Subjek penelitian ini adalah mahasiswa Fakultas Pendidikan dan Keguruan Universitas Islam Negeri Syarif Hidayatullah Jakarta yang diambil dengan teknik simple random sampling. Pengumpulan data dilakukan melalui wawancara semi struktural dengan modus subjektivitas Abdullah Sahin berdasarkan kerangka kerja James Marcia. Dengan demikian, penelitian ini menemukan bahwa subjek dalam status penyitaan, moratorium dan pencapaian, dan tidak ada responden yang berstatus difusi. Kebaruan dari penelitian ini adalah bahwa agama memberikan setting yang berbeda untuk eksplorasi identitas dan komitmen melalui penawaran konteks ideologis, sosial dan spiritual.
\end{abstract}

Kata Kunci: subjektivitas keagamaan, remaja akhir, wawancara semi-terstruktur

\section{PENDAHULUAN}

Agama adalah domain ideologis penting pada masa remaja akhir[1]. Maka memahami pengalaman keagamaan remaja akhiradalah penting mengingat perkembangan identitas substansial yang terjadi selama periode ini. Di Indonesia, domain agama memiliki peran sentral dalam kehidupan warga negara dengan sila pertama Pancasila adalah Ketuhanan Yang Maha Esa. Para peneliti pun mengakui agama sebagai domain penting pembentukan identitas sebagaimana pemikiran Eric Erikson tentang perkembangan psikososial manusia. Erikson menganggap bahwa ekspresi agama dan spiritualitas berkontribusi membentuk identitas yang sehat [2].

Remaja akhir merupakan periode penyesuaian diri terhadap pola-pola kehidupan baru dan harapan-harapan sosial baru, serta bersikap mandiri [3]. Masa remaja akhirdimulai pada awal usia 20 - 30-an [4]. Usia 20 - 30-an jika dikaitkan dengan pendidikan merupakan usia dimana individu berstatuskan mahasiswa dan sedang menjalankan pendidikannya di jenjang perguruan tinggi. Sesuai dengan tugas perkembangannya, usia mahasiswa sudah menemukan identitasnya. Eric Erikson menyampaikan bahwa fase individu mencari identitasnya adalah masa remaja, ketika individu menginjak masa dewasa 
awal, maka individu sudah seharusnya berhasil menemukan identitasnya. Identitas tersebut terdiri dari berbagai aspek, salah satunya adalah identitas keagamaan [5].

James E. Marcia, seorang psikolog di bidang klinis dan perkembangan, mengembangkan gagasan Eric Erikson mengenai eksplorasi dan komitmen yang merupakan dua elemen penting untuk membentuk identitas diri. Eksplorasi merupakan masa ketika individu secara aktif terlibat dalam penentuan pekerjaan dan keyakinannya. Komitmen mengacu pada tingkat investasi individu terhadap pekerjaan atau keyakinannya [6]. Abdullah Sahin menggunakan mode subjektivitas Marcia untuk mengetahui subjektivitas keagamaan remaja muslim di UK dan Kuwait. Subjektivitas keagamaan dibedakan menjadi empat tipologi yaitu: diffusion, foreclosure, moratorium dan achievement [6][8].

Faktor-faktor yang mempengaruhi religious subjectivity individu pada awalnya adalah keluarga, kapasitas kognitif yang berkembang, dan juga kondisi sosial-budaya. Saat ini, kondisi sosial-budaya di Indonesia sudah tercemari oleh era globalisasi yang memiliki pengaruh besar terhadap gaya hidup individu. Hal inilah yang menjadi salah satu faktor penyebab sedikitnya orang dewasa muda yang melakukan eksplorasi terhadap keagamaan, sehingga menyebabkan berkurangnya orang dewasa muda yang memiliki komitmen terhadap keagamaan, dengan begitu maka religious subjectivity pada masa muda pun menjadi beragam.

Beragamnya religious subjectivity tersebut juga ditemukan pada mahasiswa, seperti yang terjadi pada mahasiswa tingkat akhir FITK UIN Jakarta. Dalam upaya mencapai tujuannya, universitas mewajibkan mata kuliah PAI, di samping itu terdapat kegiatan keagamaan yang difasilitasi oleh organisasi-organisasi keagamaan baik di tingkat universitas maupun fakultas, serta lingkungan sosial yang religius. Hal tersebut merupakan kesempatan bagi mahasiswa untuk melakukan eksplorasi terhadap keagamaan. Harapannya seluruh mahasiswa dapat menghayati dirinya sebagai generasi muda dengan identitas muslim yang unggul, dimana nilai-nilai Islam tidak hanya dipelajari saja, tetapi juga tertanam dalam hati dan diaplikasikan dalam kehidupan. Dengan begitu maka terbentuk komitmen terhadap keagamaan pada diri mahasiswa-mahasiswa di FITK UIN Jakarta. Namun dalam kenyataannya, subjektivitas keagamaan yang ditunjukkan beragam.

Berdasarkan latar belakang yang telah diuraikan, maka perumusan masalah dalam penelitian ini adalah sebagai berikut: "Bagaimana gambaran religious subjectivity pada mahasiswa tingkat akhir FITK UIN Jakarta?". Selanjutnya, tujuan dalam penelitian ini adalah memperoleh data empiris mengenai gambaran religious subjectivity mahasiswa tingkat akhir FITK UIN Jakarta.

\section{LANDASAN TEORI}

Menurut Encyclopedia Britannica, agama dapat dikatakan subyektif setidaknya dalam dua pengertian. (1) praktik agama melibatkan pengalaman batin, seperti perasaan Tuhan yang membimbing kehidupan penyembah. Di sini agama melibatkan subjektivitas dalam arti pengalaman individu. (2) Agama juga dapat dianggap subyektif karena kriteria kebenarannya diputuskan tidak jelas dan sulit didapat, sehingga tidak ada tes obyektif yang jelas [9]. Penelitian ini menitik beratkan pada pengertian agama dalam cakupan pengalaman individu.

Griffith \& Griggs mendefinisikan subjektivitas keagamaan sebagai kerangka konseptual yang didefinisikan oleh eksplorasi dan komitmen dalam bidang keagamaan [10]. Peneliti lain, Cohen-Malayev et al mendefinisikan subjektivitas keagamaan sebagai definisi diri seseorang dan signifikansinya yang berasal dari agama dalam definisi diri seseorang. Dimana pengkategorian James Marcia (diffusion, foreclosure, moratorium dan 
achievement) digunakan untuk mendeskripsikan berbagai cara orang beradaptasi dan menjalani keyakinan mereka [11].

Eksplorasi adalah periode dimana ada keinginan untuk berusaha mencari tahu, menyelidiki berbagai pilihan yang ada dan aktif bertanya secara serius untuk mencapai sebuah keputusan tentang tujuan yang akan dicapai, nilai dan keyakinan. Komitmen adalah suatu periode dimana ada pembuatan pilihan yang relative tetap mengenai aspek-aspek identitas seseorang dan terlibat dalam aktivitas yang secara signifikan mengarah kepada pilihan yang sudah diambil [6]. Berdasarkan proses eksplorasi dengan mencari tahu, menyelidiki dan bertanya secara serius, remaja membahas informasi keagamaan dan spiritual yang didapatkan dari keluarga dan budaya, kemudian mencari keyakinan agama dan spiritual sendiri yang menuntun berkomitmen berdasarkan perspektif mereka.

Diffusion adalah status individu yang tidak menunjukkan adanya eksplorasi, seperti tidak memiliki ketertarikan pada agama dan kemungkinan mereka berorientasi ekstrinsik pada agama mereka [10]. Individu kurang berminat pada agama dan tidak pernah benarbenar menjelajahi agama dan sedikit keinginan untuk melaksanakan agama. Individu tidak berkomitmen pada serangkaian nilai dan tujuan yang konsisten secara internal [7]. Bisa jadi seseorang tidak tertarik identitas sama sekali dan belum mengalami pencarian secara internal atau telah mencari makna dan telah menemukan sumber identitas selain agama [12].

Foreclosure menggambarkan individu yang sudah dapat membentuk komitmen keagamaan dan juga dapat mengaplikasikannya. Namun mereka tidak melakukan eksplorasi terhadap keagamaannya, sehingga komitmen yang dijalani tidak diiringi dengan landasan yang jelas [10]. Komitmen bukan berasal dari pencarian sendiri, tapi pengaruh orang disekitarnya [7].

Karakteristik individu dengan status moratorium tidak menunjukkan adanya komitmen keagamaan atau komitmennya didefinisikan secara kabur, dan bisa terus menerus memperhatikan identitasnya [10]. Pada level ini tekanan untuk menyesuaikan diri mulai mereda dan individu mulai memeriksa diri sendiri dan mempertanyakan siapa mereka dan apa yang mereka yakini. Refleksi diri yang dibimbing oleh penyelidikan spiritual yang tulus, memberikan keberanian untuk mengakui dan bergerak melampaui religiusitas yang mementingkan diri sendiri atau konformis. Pada tahap ini mereka sedang dalam proses merumuskan dan menginternalisasi kepercayaan spiritual. Menurut Sahin, moratorium bukan benar-benar status, tetapi suatu proses eksplorasi dan pertanyaan yang diperlukan untuk munculnya identitas yang dikonstruksi secara pribadi [7].

Achievement menggambarkan individu yang telah mengalami krisis dan membuat komitmen [10]. Peneliti lain menggunakan kata integration sebagai pengganti achievement dari Marcia untuk menghilangkan nilai-nilai implisit dari berbagai teologi dan tradisi yang membentuk identitas agama [12]. Empat tipologi subjektivitas keagamaan (religious subjectivity) di atas digambarkan dalam tabel berikut ini: 
Table 1. Tipologi Subjektivitas Keagamaan

\begin{tabular}{|c|c|c|c|}
\hline Diffusion & Foreclosure & Moratorium & Achievement \\
\hline $\begin{array}{l}\text { Komitmen agama } \\
\text { rendah dan tidak ada } \\
\text { eksplorasi }\end{array}$ & $\begin{array}{l}\text { Komitmen agama } \\
\text { tinggi, tidak ada } \\
\text { eksplorasi }\end{array}$ & $\begin{array}{l}\text { Komitmen agama } \\
\text { rendah tetapi } \\
\text { ditandai dengan } \\
\text { eksplorasi } \\
\text { berkelanjutan. }\end{array}$ & $\begin{array}{l}\text { Komitmen agama } \\
\text { tinggi dan } \\
\text { menunjukkan nalar } \\
\text { dialogis. }\end{array}$ \\
\hline
\end{tabular}

\section{HASIL DAN PEMBAHASAN}

Perkembangan identitas responden dianalisa menggunakan tipologi subjektivitas keagamaan yaitu diffusion, foreclosure, moratorium dan achievement. Menurut Sahin, analisis psikososial ini bisa digunakan untuk menentukan status praktik pengajaran Islam dan menilai keberhasilan praktik pengajaran yang ada. Responden dianalisis dengan menerapkan seperangkat kriteria penilaian untuk membedakan proses komitmen dan eksplorasi psikososial dalam kehidupan keagamaan dari Abdullah Sahin sebagai berikut: [7]

Kriteria ada tidaknya proses eksplorasi:

a. Individu muslim yang memiliki minat aktif dalam meningkatkan pengetahuan dan pemahaman tentang Islam dan aktif mencari informasi tentang pilihan alternatif menjadi seorang Muslim, termasuk kemungkinan menjadi non-religius karena keraguan dalam hubungannya menjadi muslim muda dalam konteks multikultural.

b. Menimbang kelebihan dan kekurangan dalam memberikan interpretasi Islam pada kehidupan.

c. Kesediaan untuk mencerminkan dan mempertimbangkan komitmen awal dari orang tua, teman atau orang yang menurutnya penting.

d. Sikap terhadap interpretasi historis dan kontemporer yang berbeda tentang Islam dan tingkat kesadaran dan pengakuan terhadap keragaman agama, budaya dan ideologis-politik dalam masyarakat yang lebih luas.

e. Emosi yang mengekspresikan keterikatan pada Islam dan bagaimana mengartikulasikan keragua-raguan dalam kehidupan beragama.

f. Ada keinginan membuat keputusan awal tentang komitmen atau keterlibatan dalam praktik keagamaan.

Kriteria ada tidaknya komitmen:

a. Komitmen secara pribadi mengenai aspek keagamaan Islam.

b. Adanya kegiatan yang diarahkan untuk mengimplementasikan elemen-elemen religiusitas Islam yang dipilih dalam kehidupan atau upaya aktual mempraktikkan ajaran Islam.

c. Adanya emosi dan ekspresi diri dan keinginan untuk mencapai resolusi ambiguitas dalam kehidupan keagamaan.

d. Identifikasi dengan nilai-nilai Islam dan mampu memproyeksikan nilai-nilai ini ke dalam diri di masa depan.

Remaja yang menempuh pendidikan Perguruan Tinggi, mengalami babak transisi dalam hidupnya yaitu berpindah dari jenjang sekolah menengah menuju jenjang Perguruan 
Tinggi. Perpindahan ini melahirkan beberapa dampak bagi remaja, baik dampak positif maupun dampak negatif. Mahasiswa yang rendah eksplorasi dan komitmennya rentan terjerumus ke dalam fenomena kebingungan identitas yang dapat termanifestasi dalam perilaku-perilaku negatif. Meski demikian, ada pula sebagian mahasiswa lainnya yang mampu lepas dari jebakan kebingungan identitas tersebut dan melahirkan perilaku-perilaku yang dinilai positif oleh lingkungan.

Haris menyebutkan;

Kalau lagi rajin saya suka salat awal waktu ke masjid. Semakin kesini saya semakin susah untuk beribadah, padahal kalau saya salat awal waktu ke masjid, hidup jadi tenang dan banyak tugas menjadi plong.

Partisipasi dalam kegiatan keagamaan hampir di bagian bawah daftar prioritasnya. Alasan ini menguatkan penulis memasukkan Haris dalam foreclosed religiosity. Keagamaan yang dibina orang tua atau pendidikan sebelumnya dengan doktrin hukum nir substansi membuat Haris ketika masuk ke perguruan tinggi sulit mengatur kegiatan hidupnya antara belajar, tugas kuliah dan ibadah. Dia tidak aktif menghadiri masjid, aktivitas salatnya menjadi tertunda dan terlewatkan karena sibuk dengan kuliah dan kecanduan ponsel game. Komitmen agama dipengaruhi keluarga yang mengajarkan keislaman sebagai kewajiban yang harus dilaksanakan dan menjadi doktrin yang sudah terkonstruk dalam pikiran anak yang membentuk satu keyakinan tentang substansi hukum ibadah bukan makna ibadah itu sendiri sehingga tidak ada upaya sadar diri pada individu untuk mengeksplorasi.

Kardita menyebutkan;

Saya merasakan ada perbedaan religiusitas ketika saya mondok dengan kedisiplinan yang sedikit banyak membentuk karakter saya dalam beribadah dan beragama, salat sudah dijadwalkan termasuk salat sunnah Dhuha dan Tahajud karena lingkungan membentuk itu dan mendorong saya untuk lebih beribadah. Ketika saya masuk ke UIN, saya katakan dengan jujur religiusitas saya menurun dari yang sebelumnya puasa senin-kamis jadi lebih jarang, bahkan seperti tahajud selama saya kuliah hampir tidak pernah. Faktornya karena lingkungan dan pertemanan.

Lingkungan pesantren terdapat kultur sosial dan pola kehidupan yang tertanam dalam setiap individu santri dalam menjalani kesehariannya. Pola kehidupan yang tercipta membentuk kedisiplinan dalam beribadah dan beragama, salat wajib dan salat sunnah teratur dan terjaga. Pola hidup terkontrol kadang membuat santri tidak melakukan refleksi. Akibatnya santri mengalami tantangan berat ketika hidup dalam dunia luar yang sangat berbeda dengan kehidupan di pesantren. Beberapa alumni pesantren mengalami perubahan perilaku keagamaan dengan tujuan agar diterima di lingkungan teman kuliah dan sepermainan. Ada juga yang melakukan sebagai bentuk pelampiasan rasa tertekang selama di pondok pesantren menjadi individu yang melakukan segala hal yang didasari rasa ingin tahu dan ikut trend yang ada, mengesampingkan apa yang telah didapatkan selama di pondok pesantren. Kardita mengalami perubahan perilaku keagamaan ketika ingin diterima di lingkungan teman kuliahnya sebagaimana pengakuannya bahwa pertemanan dan kebiasaan begadang sampai malam membuat ibadah yang dulu rajin dikerjakan semasa di pesantren menjadi susah dilaksanakan, misal salat tahajjud.

Status achievement merepresentasikan status paling bagus bagi remaja. Status achievement dicirikan dengan tingkat komitmen agama tinggi dan menunjukkan nalar dialogis. Beberapa riset membuktikan bahwa remaja yang memiliki identitas matang (achievement) menunjukkan skor yang tinggi dalam berbagai aspek psikologis (meliputi self-esteem, internal locus of control, psychological well-being), memiliki profil 
kepribadian yang positif, serta memiliki kesadaran dan kestabilan emosi yang tinggi. (Schwatz, et al).

Salah satu responden bernama Ari menyebutkan refleksinya sebagai berikut;

Saya mendapatkan motivasi dari membaca kisah-kisah para Sahabat Nabi terutama Umar bin Khatab, beliau meskipun pemimpin dalam konteks khalifah saya menempatkan sebagai pemimpin bagi diri saya sendiri. Ketika kita sudah menjadi keluarga maka menjadi pemimpin bagi keluarga, ketika masih kecil, maka ayah sebagai pemimpin untuk memberikan kebenaran.

Kisah dalam Al-Qur'an, para Nabi dan Sahabat adalah metode pendidikan dalam Islam yang mampu menyentuh perasaan, mendidik jiwa dan membangkitkan semangat peserta didik. Menurut Armai Arief, kisah dapat mengaktifkan dan membangkitkan semangat karena setiap anak didik akan senantiasa merenungkan makna dan mengikuti berbagai situasi kisah, sehingga anak didik terpengaruh oleh tokoh dan topik kisah tersebut. Ari menjadikan figur Umar bin Khatab dalam kepemimpinan diri sendiri dan keluarga.

\section{PENUTUP}

Berdasarkan pembahasan yang telah diuraikan di atas, maka dapat diperoleh simpulan bahwa Religious Subjectivity yang dimiliki oleh mahasiswa tingkat akhir FITK UIN Jakarta adalah foreclosure, moratorium dan achievement.

Mengingat terdapat religious subjectivity foreclosure, yaitu individu yang menjalankan komitmen terhadap keagamaannya tanpa melakukan eksplorasi terhadap nilainilai agama itu sendiri. Maka hendaknya universitas lebih mengaktifkan kegiatan yang dapat menjadi sarana bagi mahasiswa untuk menggali nilai-nilai Islam lebih dalam lagi, dengan cara mengemas kajian Islam secara modern berdasarkan tema-tema global dan sesuai dengan fenomena masa muda saat ini.

\section{DAFTAR PUSTAKA}

[1] G. Prawitasari and S. Suwarjo, "Promoting Interventions to Develop Religous Identity of Secondary School Students," COUNS-EDU Int. J. Couns. Educ., vol. 3, no. 4, p. 140, 2018, doi: 10.23916/0020180314640.

[2] T. E. Grajales and B. Sommers, "Identity styles and religiosity: Examining the role of identity commitment," J. Res. Christ. Educ., vol. 25, no. 2, pp. 188-202, 2016.

[3] E. B. Hurlock, Psikologi Perkembangan: Suatu Pendekatan Sepanjang Rentang Kehidupan (Edisi 5), Fifth. Jakarta: Erlangga, 1991.

[4] J. W. Santrock, Life Span Development: Perkembangan Masa Hidup, Edisi 5 Jilid 2. (Penerjemah: Tri Wibowo), Fifth. Jakarta: Erlangga, 2002.

[5] G. Prawitasari, "Profil Status Identitas Religius pada Remaja Akhir," PSIKOPEDAGOGIA J. Bimbing. dan Konseling, vol. 6, no. 2, p. 104, 2018, doi: 10.12928/psikopedagogia.v6i2.9442.

[6] T. A. Klimstra and L. van Doeselaar, "18 - Identity formation in adolescence and young adulthood,” J. B. T.-P. D. A. the L. Specht, Ed. Academic Press, 2017, pp. 293-308.

[7] A. Sahin, New directions in Islamic education: Pedagogy and identity formation. Kube Publishing Ltd, 2013.

[8] A. Sahin, "Critical Issues in Islamic Education Studies : Rethinking Islamic and Western Liberal Secular," Religions, 2018, doi: 10.3390/re19110335. 
[9] Encyclopedia Britannica, "Study of religion," Encyclopadia Britannica, inc. https://www.britannica.com/topic/study-of-religion.

[10] B. A. Griffith and J. C. Griggs, "Religious identity status as a model to understand, assess, and interact with client spirituality," Couns. Values, vol. 46, no. 1, pp. 14-25, 2001.

[11] M. Cohen-Malayev, E. P. Schachter, and Y. Rich, "Teachers and the religious socialization of adolescents: Facilitation of meaningful religious identity formation processes," J. Adolesc., vol. 37, no. 2, pp. 205-214, 2014.

[12] A. Day, Religion and the individual: Belief, practice, identity. Routledge, 2016. 